\author{
MARCIN POPRAWA
}

Uniwersytet Wrocławski

\title{
Świat wynalazków i odkryć naukowych w dwudziestoleciu międzywojennym - wybrane strategie dyskursu popularnonaukowego $\mathrm{w}$ prasie
}

\section{Ustalenia wstępne}

W artykule tym przedstawiam najważniejsze strategie prasowego dyskursu popularnonaukowego lat 1918-1939. Materiał badawczy pochodzi z dwóch poczytnych gazet wybranych przeze mnie ze względu na ich zasięg oddziaływania oraz wyrazisty profil tematyczny. Pierwszą jest „Ilustrowany Kurier Codzienny” pod redakcją Mariana Dembińskiego [dalej: IKC], jeden z najważniejszych dzienników badanego okresu, zawierający dodatek świąteczny poświęcony sprawom nauki kultury i sztuki (pt. „Kurier Naukowo-Literacki” [dalej: KNL]) ${ }^{1}$. W gazecie tej systematycznie pisano o nauce — zarówno w kolumnach przeznaczonych dla przeciętnego czytelnika, jak i w dodatkach przeznaczonych dla bardziej wykształconego odbiorcy. Drugie czasopismo, z którego wybrałem materiał językowy, to „Technika, Rzemiosło, Wynalazki” [dalej: T] pod redakcją Jerzego Smolarza periodyk, którego profil należałoby zestawić ze współcześnie ukazującymi się wydawnictwami popularnonaukowymi, jak np. „Wiedza i Życie” czy „Świat Nauki", a więc z pismami adresowanymi do odbiorcy z wyższymi niż przeciętne aspiracjami czytelniczymi.

W opracowaniu tym pokazuję najważniejsze sposoby obrazowania nauki w dyskursie medialnym tamtych czasów, strategie komunikacyjne stosowane

${ }^{1}$ Dziennik „Ilustrowany Kurier Codzienny” wydawany był w Krakowie w latach 1910-1939 pod redakcją Mariana Dembińskiego. Uznawany jest przez prasoznawców za „wizytówkę prasy tamtych czasów" (chodzi o zasięg oddziaływania, profil masowy, jak i bogactwo formy, w tym ikonicznej) oraz nazywany „małą, ilustrowaną encyklopedią współczesności” (ze względu na wysoki poziom tekstów popularnonaukowych) (por. Wrona 2005; Paczkowski 1980). 
przez dziennikarzy w celu pozyskania uwagi odbiorcy zainteresowanego wiedzą popularnonaukową (czyli najogólniej: sposoby pisania w łatwiejszy sposób o trudnych tematach, por. Miodek, Zaśko-Zielińska (red.) 2002) oraz odtwarzam towarzyszący temu kontekst historyczny, kulturowy, społeczny i światopoglądowy (por. prace A. Starzec, S. Gajdy, J. Biniewicza zamieszczone w bibliografii oraz opracowania z historii Polski i historii kultury). Pokazuję również, w jaki sposób nauka, która przeżywała w latach 1918-1939 swój bujny rozkwit, zaistniała w świadomości społecznej w ,zmediatyzowanej” formie (por. artykuły zawarte w tomie pod red. B. Gruszki 2004 czy monografię T. Woźniaka 2000).

\section{Dyskurs popularnonaukowy}

Dyskurs popularnonaukowy (często w literaturze przedmiotu utożsamiany $\mathrm{z}$ dyskursem popularyzacyjnym czy stylem popularnonaukowym) zalicza się do rodziny dyskursu naukowego (obok edukacyjnego i dydaktycznego), a za najważniejszy jego cel komunikacyjny uznaje się przybliżanie wiedzy specjalistycznej — niespecjalistom.

Ten model komunikacyjny opiera się więc na nierównorzędnych relacjach nadawczo-odbiorczych. Pragmatyczny warunek powodzenia komunikacyjnego zwykle determinowany jest przez kompetencje nadawcy, który ma za zadanie „przełożyć”, „przetłumaczyć”, „przybliżyć”, ,przekazać” trudną wiedzę naukową w łatwej, przystępnej i zrozumiałej lub atrakcyjnej formie, a więc wykazać się umiejętnościami popularyzacji (upowszechniania) (Starzec 1999, 2013; Gajda 1999, 2013; Piekot 2002, także artykuły zawarte w tomie: Miodek, Zaśko-Zielińska (red.) 2002).

Popularyzację zaś można zdefiniować za Anną Starzec jako makrostrategię komunikacyjną, która „ma służyć upowszechnianiu wiedzy naukowej szerokiemu ogółowi i w tym sensie jest [ona] rodzajem ogólnego kształcenia, które pozwala człowiekowi zrozumieć otaczającą rzeczywistość" (Starzec 2002, s. 25; więcej na temat popularyzacji i jej terminologicznych ekwiwalentów w innych opracowaniach badaczki: 1997, 1999, 2013).

Wzorce tekstów popularnonaukowych/popularyzacyjnych we współczesnej odsłonie medialnej (w komunikacji medialnej) mogą pojawiać się w różnych wariantach gatunkowych, choć prymarnie wywodzą się z form związanych z działalnością dydaktyczną (jak wykład, pogadanka, gawęda, także dyskusja). Na jakość stylu, wybory tekstowe dyskursu popularyzatorskiego/popularnonaukowego ${ }^{2}$

2 Według A. Starzec najważniejsze role komunikacyjne w tekstach popularnonaukowych (oraz w popularyzacji wiedzy) wiążą się z umiejętnością nadawcy przekazania uniwersalnej wiedzy naukowej w atrakcyjnej poznawczo i tekstowo formie, a nadawca musi być z jednej strony „tłumaczem”, z drugiej „nauczycielem” (Starzec 1999). Według T. Piekota teksty popularnonaukowe 
wpływają: porządek nadawczo-odbiorczy oraz powiązania ze stylem naukowym (np. świat przedstawiony w tekstach, zawartość poznawcza, abstrakcyjność wypowiedzi) oraz stylem publicystycznym (głównie na poziomie budowania dialogowych strategii docierania do odbiorcy/czytelnika, nacechowania emocjonalnego i aksjologicznego komunikatów oraz języka figuratywnego opartego na analogiach, przykładach i wzorcach egzemplifikacji). Jest to więc sposób komunikacji, w którym ujawniają się , cechy peryferyjne tekstów naukowych, a centralne dla publicystycznych i artystycznych" (Zdunkiewicz-Jedynak 2008, s. 128; por. także Piętkowa 2005).

Prasowy dyskurs popularyzatorski zawiera zaś strategie tekstowo-stylistyczne, które są pochodną dwóch domen komunikacyjnych (i społecznych zarazem): nauki i mass mediów. $Z$ tej pierwszej zapożycza więc elementy poznawczo-informacyjne (pojęcia, wartości, zaplecze teoretyczno-faktograficzne), z tej drugiejpragmatykę pozyskiwania odbiorcy (zwykle opartą na typowych środkach języka medialnego o walorach perswazyjnych, takich jak: myślenie obrazowe i potoczne, wartościowanie i nacechowanie emocjonalne wypowiedzi, język metaforyczny).

\section{Media — kultura — popularyzacja nauki w dwudziestoleciu międzywojennym}

Upowszechnianie nauki i wiedzy naukowej — zarówno w jej wariancie teoretyczno-poznawczym (w kręgu ludzi nauki i adeptów pracy akademickiej), jak i użytkowym (funkcjonalnym, praktycznym, jako domena ludzi wykształconych zawodowo związanych z przemysłem, kulturą, oświatą itp. $)^{3}$ — było ważną dziedziną życia społecznego i kulturalnego w dwudziestoleciu międzywojennym. Słowo popularyzacja (wraz z kolokacjami: $P$. + wiedzy, nauki, derywatami popularyzacja, popularyzowanie, popularyzator i synonimami upowszechnianie, uprzystępnianie + wiedzy, wyników wiedzy/badań) $\mathrm{w}$ znaczeniu tożsamym ze współczesnym lub zbliżonym do niego (czyli 'rozpowszechnianie, uprzystępnianie społeczeństwu nauki, sztuki, wiedzy o czymś’ USJP, red. S. Dubisz) pojawiło się w rejestrze polszczyzny naukowej, jak i w obiegu potocznym już w XIX wieku (Wrona 2007, s. 19). O obowiązkach edukacyjnych uczonych i wartości światopoglądowej ich pracy popularyzatorskiej, zastępującej często niedostatki oświaty i braki programów nauczania, rozprawiano w czasopismach naukowych, specja-

\footnotetext{
(głównie medialne, prasowe) są zwykle wtórne wobec naukowych, popularyzacja zaś ,jest przystosowaniem dyskursu naukowego do zmienionych warunków komunikacyjnych, a jej głównym celem jest zwiększenie przystępności i atrakcyjności powstającego tekstu" (Piekot 2002, s. 41).

${ }^{3}$ O funkcji poznawczej i technologicznej (użytkowej) nauki w: (Gajda 2013, s. 62).
} 
listycznych i popularyzatorskich już w drugiej połowie XIX wieku, a sytuacja ta utrzymywała się również w dwudziestoleciu międzywojennym ${ }^{4}$.

Ze znaczeń zawartych $\mathrm{w}$ opracowaniach leksykograficznych i encyklopedycznych powszechnie dostępnych $\mathrm{w}$ tym czasie $^{5}$ wyłaniają się najważniejsze właściwości omawianego dyskursu, a więc: działalność edukacyjna ludzi nauki (popularyzatorów, uczonych), którzy przedstawiają wyniki swoich badań i ważne teorie naukowe dla szerokich mas, szerokiego ogółu społeczeństwa w sposób dostępny, przystępny i zrozumiaty.

Świat wynalazków i odkryć naukowych wkroczył na łamy prasy codziennej i specjalistycznej z kilku powodów: po pierwsze, po odzyskaniu przez Polskę niepodległości nastąpiła modernizacja kraju ${ }^{6}$, której towarzyszył rozwój przemysłu (głównie chemicznego, wojskowego, kolejowego); po drugie, dy-

${ }^{4}$ Warto w tym miejscu przywołać przykład wypowiedzi odnotowany przez Grażynę Wronę z bardzo poczytnego czasopisma poświęconego wiedzy techniczno-przyrodniczej: „Popularyzacja nie polega na opuszczeniu trudnych kwestii, ale na przystępnym ich przedstawieniu [...], zmusza badaczy do zejścia ze swych katedr uniwersyteckich, aby pogawędzić z rolnikiem i rzemieślnikiem" (cytat ten przytaczam w całości za: Wrona 2007, s. 23).

5 Warto w skrótowym zarysie odnotować, że w XIX wieku nastąpiło przesunięcie znaczenia pojęcia popularyzacji ze sfery związanej z działalnością społeczno-polityczną w kierunku działalności społeczno-edukacyjnej czy kulturowej. Przykładowo w Encyklopedii powszechnej Samuela Orgelbranda wydanej w Warszawie w 1865 roku pojawia się hasło popularność tłumaczące upowszechnianie wiedzy w znaczeniu wtórnym wobec działalności społeczno-politycznej; czytamy w niej: „Drugim rodzajem popularności jest pisarstwo, lub w ogóle wysłowienie się w przedmiotach nawet ściśle naukowych, przystępne i zrozumiałe dla ogółu, a przynajmniej dla ludzi specjalnie z temi naukami nieobeznanymi. Wykład podobnie przystępny zowie się popularnym” (t. 21, s. 338). Podobnie w Stowniku języka polskiego pod redakcją M. Orgelbranda (tzw. wileńskim, 1861) odnotowane są jako prymarne znaczenia odnoszące do sfery politycznej, np.: popularyzować (z franc.) — ,upowszechniać, robić przystępnym dla wszystkich”; popularyzowanie — ,jednanie przychylności ludu dla siebie”; popularysta — „ubiegający się o względy ludu, demokrata”. Z kolei już w Stowniku języka polskiego J. Karłowicza, A. Kryńskiego i W. Niedźwiedzkiego (tzw. warszawskim, 1900-1927) odczytamy znaczenia prymarnie związane z upowszechnianiem trudnej wiedzy przez specjalistów dla niespecjalistów, np.: popularyzować - „uprzystępniać, rozpowszechniać, czynić dostępnym dla ogółu np. wiedzę czy także wydawnictwa, przystępne i łatwo zrozumiałem wykłady". O stabilizacji znaczeniowej omawianego pojęcia — związanej w działalnością edukacyjną i światopoglądową pracowników naukowych - świadczą z kolei hasła zawarte w najczęściej wykorzystywanych w pierwszej połowie XX wieku wydawnictwach encyklopedycznych, m.in. w: 1) Encyklopedii powszechnej z ilustracjami i mapami Samuela Orgelbranda (Warszawa 1902): popularyzacja — „uprzystępnienie wyników wiedzy szerokiemu ogółowi”; popularyzator — „uczony, który wykłada w sposób przystępny dla ludzi mało wykształconych" (t. XII, s. 205); 2) Ilustrowanej encyklopedii Trzaski, Everta i Michalskiego (Warszawa 1927): popularyzacja — „uprzystępnianie wyników wiedzy szerokiemu ogółowi”; popularyzator — „uczony, który szerzy wiedzę w sposób dostępny dla szerokich mas" (t. IV: 475); 3) Wielkiej ilustrowanej encyklopedii powszechnej Wydawnictwa Gutenberga (Kraków 1929-1938) popularyzator — ,uczony, przedstawiający wyniki wiedzy w formie łatwo zrozumiałej, dostępnej dla ogółu" (t. XIV, s. 38) (w wydawnictwie tym nie pojawia się już hasło popularyzacja).

${ }^{6}$ Tu warto przypomnieć najważniejsze projekty: reformę finansowo-gospodarczą W. Grabskiego, modernizację Górnośląskiego i Centralnego Okręgu Przemysłowego, budowę portu w Gdyni, rozbudowę przemysłu chemicznego i ciężkiego na skutek reform E. Kwiatkowskiego i I. Mościckiego. 
namicznie rozwijała się nauka polska i zreformowano szkolnictwo (choć nie udało się do 1939 roku całkowicie usunąć analfabetyzmu wśród niższych grup społecznych); po trzecie, nastąpiły przeobrażenia w kulturze, polegające na jej umasowieniu i egalitaryzacji, a z jej najważniejszych mediów, przyjmowanych jako osiągnięcia cywilizacyjne (np. radio $^{7}$, kino), korzystały coraz szersze kręgi obywateli. Nauka stała się więc obiektem refleksji na poziomie treści lansowanych przez media masowe - obok bieżącej informacji i publicystyki. Wśród inteligencji i wykształconych warstw pozostały również dawne przyzwyczajenia czytelnicze, wywiedzione z czasów zaborów - mowa tu o lekturze periodyków na temat wypraw geograficznych, przyrody, antropologii, nauki scjentystycznej itp. ${ }^{8}$

Kultura, nauka i oświata polska w dwudziestoleciu międzywojennym mimo wielu niedostatków (administracyjnych, finansowych, społecznych) i spuścizny porozbiorowej (np. analfabetyzm, bardzo niski współczynnik scholaryzacji, niski stopień urbanizacji, brak dostępu niższych warstw społecznych do kultury) — rozwijała się w sposób burzliwy, nadrabiając zaległości i dorównując nauce światowej. Osiągnięcia polskich badaczy weszły do kanonu światowej literatury naukowej, wywołując twórczy ferment i wnosząc wiele do międzynarodowej formacji naukowej, a niektóre osiągnięcia i wynalazki z zakresu techniki, inżynierii (np. konstrukcje samolotów sportowych i wojskowych) zostały spożytkowane w rodzimym przemyśle albo spopularyzowane przez specjalistów z zachodnich koncernów badawczych i przemysłowych ${ }^{9}$. Nie sposób w tym artykule omówić wszystkich dokonań, nawet syntetyczny przegląd dziejów nauki polskiej okresu międzywojennego wykraczałby poza ramy formalne tego opracowania i miałby

7 Polskie radio rozpoczęło swe codzienne audycje w 1925 roku, w 1937 rozgłośnia Polskiego Radia nadawała już dwa programy, a w większych miastach II Rzeczypospolitej istniały już w tym czasie redakcje lokalne.

8 Podstawy prasowego dyskursu popularyzatorskiego zostały stworzone w XIX wieku. Początkowo naśladowano wzorce poczytnych czasopism europejskich (np. „Journal des Voyages”, „London Magazine”). Za najważniejsze czasopisma polskie, na łamach których pisano w łatwy i przystępny sposób o bieżących odkryciach, teoriach naukowych, a także rozwijających się paradygmatach scjentystycznych, uznaje się: kwartalnik „Przyrodnik” (od 1871), czasopismo „Przyroda i Przemysł” (od 1872), oraz „Wszechświat” (od 1882, pod redakcją Bronisława Znatowicza). Ten ostatni tytuł swą formą nawiązuje do popularnego angielskiego czasopisma „Nature”, a o jego wyjątkowym znaczeniu świadczy to, że jako jedyne polskie czasopismo popularnonaukowe ukazuje się do dziś — informacje podaję za: (Wrona 1999, 2007).

9 Najważniejsze informacje o dziejach nauki, techniki i oświaty dwudziestolecia międzywojennego w syntezach historycznych (Davies 2008; Brzoza, Sowa 2006; Kaczmarek 2010). Rozwój prasy codziennej, publicystycznej i specjalistycznej (w tym naukowej i popularyzującej wiedzę i kulturę) omawia w swej monografii A. Paczkowski (1980). Tło kulturowe i stan nauki polskiej omówiony w sposób wyczerpujący i przeglądowy w pracach z zakresu bibliologii poświęconych wydawnictwom naukowym i prasie upowszechniającej wiedzę naukową — głównie artykuły i monografie G. Wrony (1999, 2005, 2007). Najważniejsze dokonania polskiej nauki przedstawia M. Bogucka (2008), natomiast rozwój polskiej techniki, osiągnięcia badawcze i odkrycia omawia B. Orłowski (2012). 
charakter selektywny. Warto te rozważania wstępne zamknąć konstatacjami Marii Boguckiej:

Trudno chyba znaleźć w dziejach Polski okres tak krótki — zaledwie 20 lat - a tak płodny i istotny dla kultury (Bogucka 2008, s. 425);

Dystans między nauką światową a polską uległ szybkiej niwelacji [...] w nauce weszliśmy do ścisłej czołówki światowej (Bogucka 2008, s. 421-425).

Wymieńmy najważniejsze procesy, które wywoływały „ogólnonaukową aurę intelektualną" w opisywanym okresie (Gajda 2013; por. Kowalewska 1989 i in.) ${ }^{10}$, a przez to determinowały kontekst (socjo)kulturowy komunikacji popularnonaukowej (Starzec 1999; Biniewicz 2011). Są nimi:

- egalitaryzacja kultury i jej umasowienie - m.in. dostęp do prasy codziennej i fachowej, rozwój radiofonii (która oprócz bogatej agendy informacyjnej oferowała rozrywkę i edukację) (por. Paczkowski 1980; Bogucka 2008);

— mecenat państwowy i polityka oświatowo-naukowa - powstanie Polskiej Akademii Umiejętności w 1919 roku, czterech uczelni technicznych oraz licznych towarzystw naukowych i ośrodków badawczych - współpracujących także z przemysłem i gospodarką; reformy szkolnictwa podstawowego (wraz z obowiązkiem ukończenia szkoły powszechnej) i średniego (wydzielenie gimnazjów i liceów, ujednolicenie programów nauczania oraz wymagań egzaminu maturalnego);

— rozwój wydawnictw naukowych i fachowych, działalność edukacyjna ośrodków naukowych i towarzystw naukowych — wiele polskich periodyków naukowych trafiało na światowe listy bibliograficzne, a w gronie inżynierów, techników i dziennikarzy specjalizujących się w nauce za modne uchodziło czytanie literatury popularnonaukowej i specjalistycznej ${ }^{11}$.

${ }^{10}$ Stanisław Gajda wywodzi ten metaforyczny termin z filozoficznego pojęcia ducha czasu (niem. Zeitgeist) i uznaje za jeden z czynników kulturowych determinujących rozwój wiedzy naukowej i jej społecznej recepcji — jest to „mniej lub bardziej zwarty zespół idei, przekonań i zasad, które realnie oddziałują na ludzkie myślenie i zachowanie praktyczne w pewnej społeczności w określonym czasie" (Gajda 2013, s. 61).

11 Według kwerendy opracowanej przez Grażynę Wronę (2007) po 1918 roku powstało ponad 500 czasopism naukowych, spośród których $1 / 4$ miała zasięg międzynarodowy i wydawana była w językach konferencyjnych (angielskim, francuskim, niemieckim). Z kolei Andrzej Paczkowski (1980) szacuje, że 1/3 wszystkich wydawnictw prasowych stanowiły czasopisma o charakterze popularyzacyjnym — jako oddzielne periodyki przeznaczone dla inteligencji uzupełniającej swą wiedzę zawodową, jak również dla szerokiego grona czytelników jako dodatki do prasy codziennej (w tym przeznaczone dla młodzieży). 


\section{Obraz nauki i odkryć naukowych w prasie dwudziestolecia międzywojennego}

W dwudziestoleciu międzywojennym prasa była podstawowym narzędziem komunikacji masowej. Oferowała odbiorcy masowemu przebogatą i różnorodną tematykę propagandową (polityczno-ideologiczną) (por. Paczkowski 1980, 2004), wyznaczała też w dyskursie publicznym kanony kultury (przede wszystkim wysokiej, elitarnej). Sprawy nauki (informacje o bieżących osiągnięciach teoretycznych, dyskusje filozoficzne i spory światopoglądowe toczone przez autorytety świata akademickiego oraz ówczesne elity symboliczne) interesowały więc wymagającego, wykształconego odbiorcę, dla pozostałych grup społecznych gazety — z powodu ubóstwa, braku dostępu do innych źródeł kultury i słabszego wykształcenia — stawały się jedynym dostępnym ,nośnikiem wiedzy i informacji” (określenie A. Pawłowskiego 2011). Wiedza z różnych dyscyplin naukowych (od humanistyki po dziedziny nauk społecznych, przyrodniczych i ścisłych) przekazywana była przez wykształconych dziennikarzy, specjalistów pracujących na co dzień w ośrodkach badawczych (np. inżynierów, techników), intelektualistów i badaczy zaangażowanych w działalność licznych towarzystw naukowych.

Wydaje się, że w latach 1918-1939 w obrębie dyskursu prasowego podejmującego na swych łamach tematykę naukowo-kulturalną powstawały zalążki paradygmatu medialnego, który określa się we współczesnej literaturze medioznawczej ,edurozrywką" i ,edutainmentem” (czyli połączeniem informacji z edukacją oraz edukacji z rozrywką) (Lisowska-Magdziarz 2011). Oczywiście, standardy tych formatów medialnych podlegały rygorom kultury wysokiej. Teksty popularnonaukowe badanego okresu zawierały dodatkowo treści, które nie były profilowane wyłącznie na użytek upowszechniania wiedzy — odsłaniały bowiem sytuację nauki w kraju, jej kontekst społeczny, kulturowy i polityczny (czyli tym samym aktualną ,politykę naukową/edukacyjną” — Starzec 2013; , prestiż nauki” — Gajda 2010).

Czytelnik gazet i periodyków popularnonaukowych mógł więc dowiedzieć się, co ostatnio wynaleziono i jak ocenić tego przydatność. Z powodu niewspółmiernie uboższych — w porównaniu z XXI wiekiem — nośników informacji proces „medializacji nauki” (Gruszka (red.) 2004) przebiegał na łamach wysokonakładowej prasy.

O społecznych oczekiwaniach związanych z popularyzacją wiedzy naukowej w prasie codziennej i specjalistycznej świadczy również to, że wiedza ta, podawana w atrakcyjnej dziennikarskiej formie, była dla przeważającego grona odbiorców namiastką nieosiągalnych podręczników i źródeł encyklopedycznych, a dla bardziej zamożnych lub wymagających — atrakcyjną rozrywką intelektualną.

Bujny rozwój nauki, poświadczony wieloma sukcesami polskich badaczy (np. w prasie przez całe dwudziestolecie pojawiały się biografie, wspomnienia i objaś- 
nienia prac Marii Curie-Skłodowskiej) i ich wkładem w rozwój nauki światowej, spowodował, że w świadomości społecznej utrwalił się wzorzec naukowca, badacza, odkrywcy, ,,autorytetu świata uczonych” (Goćkowski 1984). Wielu też przedstawicieli świata akademickiego podejmowało społeczną działalność edukacyjną, co wpłynęło na rozwój gatunków popularnonaukowych — np. w prasie utrzymywała się tradycja felietonistyki naukowej, a w latach trzydziestych w radiu, które włączyło się w proces edukacji społecznej, pojawiły się wykłady, pogawędki czy gawędy popularnonaukowe ${ }^{12}$. Zamykając ten wątek rozważań, trzeba powiedzieć, że media dwudziestolecia dały ludziom nauki (ekspertom i intelektualistom) możliwość prowadzenia działalności edukacyjnej na skalę masową, niespecjalistom zaś - łatwy i powszechny dostęp do świata wiedzy, który dotąd ograniczał się do sal wykładowych uniwersytetów i towarzystw naukowych ${ }^{13}$.

Opisane problemy, a więc przede wszystkim pochwałę dokonań naukowych i powszechne zainteresowanie praktycznymi dla społeczeństwa i gospodarki kraju rozwiązaniami, oddaje płaszczyzna ideacyjna omawianego dyskursu (a więc zawarta w wielu przekazach sfera treści i rama semantyczna). Na podstawie materiału źródłowego udało się wyznaczyć poniższe składniki obrazowania (fasety — por. Bartmiński 2006), pokazujące portret uczonych, ocenę ich pracy, a także sposób kreowania świata, o którym pisze nadawca tekstu popularnonaukowego:

— 'nauka i wiedza' to: ożywcza i owocna praca badawcza; systematyka, która orientuje nas wśród niezliczonej mnogości zjawisk; nie bawiąc się w hipotezy, zabrała się do realnej pracy;

12 Dzieje popularyzacji wiedzy lingwistycznej (w tym przede wszystkim kultury języka) zostały wszechstronnie opisane w podręcznikach i monografiach językoznawczych (m.in. w pracach A. Markowskiego, J. Miodka, M. Bugajskiego). Warto dodać, że w prasie, którą przeglądałem w czasie przygotowywania tego artykułu (w dodatku kulturalnym do „Ilustrowanego Kuriera Codziennego"), z niezwykłym zaangażowaniem pisano m.in. o osiągnięciach filologicznych i historycznojęzykowych związanych z docieraniem do starożytnych źródeł (np. IKC z 12 marca 1928: „przyniósł sensacyjną wiadomość o badaniach [...], które miały doprowadzić do rozwiązania zagadki języka etruskiego”; IKC z 6 lutego 1930: „W poszukiwaniu za oryginalnym tekstem Starego Testamentu" lub cykl artykułów oraz dyskusji prof. Dybowskiego i prof. W. Bujwida o przydatności języka esperanto w 1927 roku).

13 Warto dodać, że wielu ekspertów nauki prowadziło na łamach gazet dyskusję na temat znaczenia popularyzacji, która miała wychowywać i chronić przed nadużyciami wynikającymi z zabobonów (np. w dziedzinie medycyny), por. tytuł artykułu Przesąy a popularyzacja nauki (KNL z 4 listopada 1926). W wielu artykułach przedstawiciele świata nauki żalili się wreszcie na stan rodzimej dyskusji naukowej (a właściwie na brak popularyzacji wiedzy), co — według dziennikarzy — przekładać się miało również na niski poziom kultury naukowej w Polsce i przewagę wiedzy teoretycznej nad praktyczną w nauczaniu uniwersyteckim. M.in. we fragmencie artykułu z IKC: „Nasze gimnazja kładą cały nacisk na to, ażeby młodzież nauczyła się pisać. Wychodzi to dopiero na wiecach uniwersyteckich, na których [...] gadatliwość, powtarzanie się, nieumiejętność ścisłego ujęcia kwestii, brak elegancji w używaniu wyrażeń, oto niektóre wady akademickich dyskusyj" (IKC z 26 października 1927). 
— 'Iudzie nauki' określani jako: umysty; koła i środowiska fachowe; wybitni uczeni; wybitni fachowcy; (młodzi) pionierzy postępu; wynalazcy, odkrywcy;

— 'ich działania': obwieścili światu sensacyjny wynik; zaskarbili sobie wiele szacunku; imię jego pozostanie w historii wynalazków okryte promienną aureola; problem ten zostanie szczęśliwie rozwiąany; wielki krok naprzód w...;

- 'osiągnięcia badawcze/naukowe': gratulować polskiej nauce tych zdobyczy; przyjać ten rewelacyjny wynik hucznymi oklaskami; podnosić poziom (wiedzy, świadomości społecznej...); zelektryzowata nas wiadomość o odkryciu; „,cuda" techniki; wzbudzaja największa sensację; sensacyjne zdobycze; jedno z najciekawszych udoskonaleń; arcydzieło (techniki);

- 'perspektywa czasowa, w której opisuje się wynalazki i odkrycia naukowe': dzisiaj realizacja ... następuje w takim tempie, że... umyst ludzki nie przestaje pracować/nie nadąza za ...; okres prawdziwych czarów; coś wciąż fascynuje badaczy; historyczny przebieg prac naukowych; stworzenie nowej epoki; epoka, która poderwała ustalone zasady (naukowe, scjentyzmu); (s)tworzenie nowej epoki; niepodobna było zatrzymać postęp;

- 'cel/przeznaczenie/perspektywa badań/odkryć/wynalazków': ma przed soba wielka przyszłość; pogłębia nasza znajomość świata; triumf filmu kolorowego będzie tym bardziej zupetny i bezwzględny, że nowy produkt będzie dostępny dla wszystkich; (przetomowe, wielkie) znaczenie tego polskiego wynalazku dla naszego kraju; możność wielorakiego zastosowania; odkryła jednocześnie nowe, potężne źródto energii, przy pomocy którego uda się, być może, ludziom opuszczać ziemię i zwiedzać ciała niebieskie;

— 'jakość, właściwość, cecha': praktyczny; ujęty nowocześnie i uwzględnia plany życiowe; gigantyczny, największy (+ spośród...); doskonalszy przy obecnych rozmiarach; pod każdym względem rewelacyjny; zdumiewajacy, niezawodny; cudowne udoskonalenia; prace te, zdawało sie syzyfowe, byly bezcennymi w swych skutkach, a plonem ich — odkrycie...; wynalazki o wiekopomnym znaczeniu; jedyny w swoim rodzaju....

W przywołanych przykładach uderza emotywizacja dyskursu i wartościowanie, w którym afirmacja świata wynalazków i odkryć naukowych przeplata się z pozytywnie nacechowanym wizerunkiem ich twórców (pionierów lub geniuszy). Dziennikarze więc wykorzystują typowe dla stylu popularnonaukowego leksemy nacechowane aksjologicznie, które wzmacniają walory perswazyjne ich tekstów (np. przymiotniki w sposób superlatywny określające „cuda nauki i techniki”: gigantyczny, doskonalszy, największy, najpotężniejszy, sensacyjny czy predykaty, które mają poruszyć odbiorcę, np. zelektryzować, wzbudzać + sensacje — por. Starzec 1999).

Ważną właściwością językowego obrazu nauki, odzwierciedlającą zarazem atmosferę panującą w kraju, powszechnie panujący nastrój reformatorski, jest płaszczyzna temporalna, która konceptualizuje czas dokonujących się na oczach odbiorców zmian w sposób dynamiczny, skokowy, przełomowy (por. Bartmiński 
2006, s. 215). Zatem czas przedstawianych wydarzeń - to okres zamykający dzieje zaborów i moment, w którym bujnie rozwijają się nowe teorie badawcze (np. nowa epoka, okres prawdziwych czarów).

\section{Wybrane strategie popularyzacji wiedzy naukowej na łamach prasy codziennej i specjalistycznej}

Najważniejszy sposób przykuwania uwagi odbiorcy artykułu prasowego sprowadza się do pragmatyczno-tekstowych właściwości nagłówków. Ich forma wyznacza ramę każdego dyskursu prasowego (por. Piekot 2006). O ile tytuły prasowe mogą pełnić różne funkcje, np. nominatywną, informacyjną, deskryptywną czy pragmatyczną (por. m.in. Pałuszyńska 2006), o tyle w artykułach popularyzujących wiedzę ważnym kryterium rozpoznawalności tekstu i jego warstwy poznawczej, a w zasadzie ważną cechą dystynktywną tego formatu medialnego, jest sama tematyka (w mniejszym stopniu gry komunikacyjne właściwe odmianie publicystycznej). Pisze o tym Anna Starzec:

Tematyka wypowiedzi jest jednym z sygnałów pozwalających rozpoznać tekst popularnonaukowy. To, że autor już w tytule bądź we wstępie mówi o odkryciu naukowym w określonej dziedzinie wiedzy, jest dla czytelnika istotną wskazówką i zapowiedzią treści, jakie będą proponowane w dalszej części tekstu (1999: 34).

Artykuły popularnonaukowe dwudziestolecia międzywojennego rozpoczynały się m.in. od 'pytań o rozwinięcie/uzupełnienie', które inicjowały ramę komunikacyjną opartą na scenariuszu wykładu. W nim dziennikarz-nauczyciel, dydaktyk stawia problem, sugerując, ,że czytelnik w artykule znajdzie na nie odpowiedź" (Stanulewicz 2002, s. 79), np. poniższe struktury składniowe z zaimkami „co/czy” w pozycjach inicjalnych:

Co jest powodem „papuziej grypy”? [IKC, 5 stycznia 1930]; Czy istnieje zwiazek między plamami stonecznymi, a zaburzeniami w atmosferze ziemskiej? [KNL, 1 listopada 1926]; Czy na Marsie jest roślinność? [KNL, 10 stycznia 1927]; Czy w mózgu mamy aparat radjowy? [KNL, 29 sierpnia 1927]; Czy i dlaczego dzieci ktamia? [IKC, 9 lutego 1930].

Ten sposób budowania relacji nadawczo-odbiorczych pojawia się rzadko w zgromadzonym materiale. Podobnie w niewielkim stopniu wykorzystywano w nagłówkach mechanizm gry komunikacyjnej (np. intertekstualnej), choć można odnaleźć przykłady:

- modyfikacji związków frazeologicznych: Technika na ustugach rozkoszy podniebienia [IKC, 2 stycznia 1931]; Miłość wiedzy silniejsza od śmierci [IKC, 6 lutego 1935]; 
— aluzji do powszechnie znanych dzieł kultury: Od czasów Tadeusza i Zosi do dni garsonki [KNL, 30 maja 1927];

— kontrastu stylistycznego 'potoczność — oficjalność'/‘żart — powaga': Panowie, zaczynamy grę... Historia świata na kartach [KNL, 1 lipca 1935];

— okazjonalnych zestawień słowotwórczych lub neosemantyzmów: Żelazna arystokracja ['parowozy'] [KNL, 12 listopada 1934]; Izograf - mechaniczny matematyk [T, 5/1938]; Maszyna do robienia gwiazd ['teleskop'] [T, 5/1938].

Nadawcy częściej wyróżniali swe teksty spośród innych za pomocą czytelnych scenariuszy komunikacyjnych, które utrwalały doświadczenia czytelników zaglądających systematycznie do znanych kolumn prasowych i dodatków poświęconych kulturze i wiedzy. Niektóre z tych artykułów były opatrzone ikonografią (głównie rysunkami i rycinami z rozmaitych kompendiów i wydawnictw encyklopedycznych), więc pierwsze spotkanie odbiorcy z tekstem nie odbywało się za pomocą sugestywnych i krzykliwych środków perswazyjnych.

Przyjrzyjmy się kilku realizacjom, które pokazują zawartość formalną (wyposażenie stylistyczne) międzywojennej prasy popularnonaukowej, a w sensie poznawczym, czyli z punktu widzenia współczesnej recepcji historyczno-kulturowej opisywanego okresu - obraz wydarzeń i społeczną świadomość tego, co się działo w sferze dokonań, projektów i teorii naukowych. Autorzy tekstów zachęcali więc odbiorców do zapoznania się z zawartością artykułów, stosując w nagłówkach m.in. następujące scenariusze komunikacyjne (częściowo zmetaforyzowane):

\section{— 'nauka i jej odkrywanie - to ciekawa przygoda':}

Zagadka tajemniczej Wyspy Wielkanocnej rozwiqzana [IKC, 1 lutego 1935]; $W$ poszukiwaniu za oryginalnym tekstem Starego Testamentu [IKC, 6 lutego 1930]; Automobilem przez Afrykę [KNL, 30 maja 1927].

\section{- 'wspólczesna nauka ma w sobie wiele magii':}

Gdy zabrzmiat glos Namiestnika Chrystusowego na falach eteru ['pierwsze przemówienie papieskie na antenie radiowej'] [IKC, 2 stycznia 1931]; Żeglowanie w eterze [KNL, 12 marca 1928]; Wspótcześni alchemicy. Maria Sktodowska-Curie, Curie Joliot [T, 5/1938]; Niebo gwiaździste na ekranie ['artykuł o pierwszy próbach uruchomienia telewizji'] [KNL, 25 stycznia 1926]; Film, który mówi [o pokazie pierwszego filmu dźwiękowego] [KNL, 1 marca 1926].

\section{— 'każde odkrycie jest sensacją naukową i medialną':}

Tajemnica zaginięcia polskich insygniów koronacyjnych wyjaśniona [IKC, 1 lutego 1936]; Kabina kapielowa, która można ... powiesić na szyji [IKC, 1 lipca 1937]; Rak uleczalny? Sensacyjne odkrycie... [IKC, 10 lutego 1937].

— 'informacje o bieżących osiągnięciach lub wynikach badań — zwykle w formie sprawozdawczej’: 
Odkrycie nowych lądów pod biegunem poludniowym [IKC, 22 marca 1931]; Budowa drapacza chmur w Katowicach [IKC, 28 maja 1931]; Nowy system budowy domów [T, 5/1938].

— 'relacje prasowe o zadziwiających i oryginalnych pomyslach (domorosłych) konstruktorów - często za pomocą scenariusza gry, konkurencji i rywalizacji, w której uczestniczą twórczy wynalazcy':

Kajak z żaglem w formie skrzydta samolotu [IKC, 11 stycznia 1930]; Oryginalny ślizgowiec wodny [IKC, 5 kwietnia 1930]; „,Parowóz” poruszany motorem Diesla [IKC, 5 kwietnia 1930]; Statek głębinowy. Doniosty wynalazek Polaka [T, 7/8 1938].

— 'racjonalna i poparta autorytetem nauki polemika z przesądami, zabobonami lub potocznymi wierzeniami':

Przesądy a popularyzacja nauki [KNL, 4 listopada 1926]; Waż morski w opinji laików i przyrodników [KNL, 22 stycznia 1934]; Przystowiowa „pracowitość" pszczół jest legenda. Najnowsze zdobycze badań naukowych nad pszczołami [IKC, 5 kwietnia 1930]; Wydarzenia, które nie znalazty żadnego wyjaśnienia. Kilka interesujacych wypadków z dziedziny okultyzmu [IKC, 26 października 1927].

\section{- '(częste) narracje/opowieści o zabarwieniu futurologicznym':}

Jakie sensacje techniczne czekaja ludzkość w najblizssym czasie? [KNL, 24 kwietnia 1929]; Samochód w roku 2000 [T, 7/1937]; Maszyna do robienia gwiazd ['planetarium'] [T, 5/1937]; Samolot, który wzbije się na 20 kilometrów ['projekty pojazdów kosmicznych'] [IKC, 22 marca 1930].

Bardzo ważna strategia popularyzacji wiedzy polega na takim zawiązywaniu relacji nadawczo-odbiorczych, aby informacje o trudnych zagadnieniach naukowych (czy praktycznych, technicznych) docierały do czytelnika w łatwiejszej formie (por. Piekot 2002). Dziennikarze międzywojnia wykorzystywali więc role komunikacyjne ,nauczyciela” i ,specjalisty”, a ich teksty miały wywoływać u odbiorcy twórczy i intelektualny niepokój, wyzwalać ciekawość poznawczą lub porządkować informacje ${ }^{14}$. W analizowanych tekstach znajdziemy przykłady „tłumaczeń" języka trudnego na język prosty:

$14 \mathrm{O}$ rolach dziennikarza-popularyzatora i zagadnieniach medializacji nauki pisze również J. Goćkowski (2004). Według przywołanego badacza dziennikarz, docierający ze swą ofertą popularyzatorską do „oświeconego obywatela” czy „eksperta”, jak i do „,człowieka z ulicy”, zobowiązany jest do pełnienia ważnej społecznie misji, która polega na: 1) 'oświecaniu' — „czyli ukazywaniu modeli świata tworzonych $w$ ramach teatru życia naukowego oraz ukazywaniu rzeczywistości obrazowanej przez uczonych [...]”; 2) 'niepokojeniu' — „przez ukazywanie problemów społecznych oraz wskazywanie na patologię w życiu uczonych"; 3) 'pouczaniu' — „Zwracaniu uwagi na problemy poznawcze typu naukowego oraz wskazywaniu na kruchość i względność prawd naukowych" (Goćkowski 2004, s. 62). 
a) najczęściej objaśniano terminy lub wyrażenia pochodzące z dyskursu naukowego, np.: „System Lembo” polega na zastrzykiwaniu osobom [IKC, 10 lutego 1937]; Dzięki metodzie Louisa Pasteura [...] od którego pochodzi wyraz pasteuryzacja [T, 5/1937];

b) lub opatrywano je kwalifikatorami, skrótami metatekstowymi: $W \boldsymbol{t}$. $\boldsymbol{z w}$. generatorach wytwarza sie gaz wodny, przez dmuchanie na rozpalony koks naprzemian powietrzem i parą wodna. Powstaje mieszanina gazów [...] [IKC, 20 stycznia 1930].

W analizowanym materiale pojawiają się również strategie komunikacyjne, za pomocą których nadawca wykorzystuje - na potrzeby swego prasowego wykładu - przekształcenia wzorców tekstowych, tak by wyzyskać efekty pragmatyczne zbliżone do dydaktyki (czyli 'nauczyć'). Są to więc mechanizmy komunikacyjne oparte na transformacjach lub adaptacjach gatunkowych, które oddziałują na czytelnika, np. poprzez:

- zamieszczanie w strukturach opisu naukowego partii tekstowych przypominających wypisy z czytanek lub tekstów poradnikowych — forma ta pojawiała się najczęściej w rozbudowanych artykułach w wydaniach prasy świątecznej lub weekendowej (np. redagowanych w otoczeniu innych felietonów):

Rozmaitością kształtu mogą też zwrócić na siebie uwagę raniuszka ogoniasta (Acredula caudata) [...] malutka ptaszyna z długim ogonkiem, który jest prawie dwa razy dłuższy od niej [Nasza czereda w jesieni $i$ zimie, KNL, 1 listopada 1926].

- powielanie wzorca instrukcji lub wykładu (dzięki któremu aktywny czytelnik, niczym uczeń/student w sali dydaktycznej, ma śledzić, a potem krok po kroku odtwarzać czynności nauczyciela) - ten wzorzec tekstowy pojawiał się w artykułach przeznaczonych dla czytelnika specjalisty:

Kiedy patrzymy na przelatującą szybko przed nami iskrę — przedstawia się ona nam jako kreska. Gdyby zamiast jednej przeleciało koło nas w szybkiej kolejności szereg iskier po torach przylegających do siebie bokami, ujrzelibyśmy przed sobą już nie kreskę, ale cały prostokąt świecący. [...] Opisana czynność tworzenia z iskier jasnego pola jest podstawą telewizji i nazywa się liniowaniem (ang. scanning) [J. Odyniec, Techniczne podstawy telewizji] [T, 7/1937].

- wprowadzanie form dialogowych (aktywizujących uwagę czytelnika) głównie w tekstach zachęcających czytelnika (obeznanego z tematem), aby ten samodzielnie zmierzył się z proponowanym zagadnieniem badawczym (por. Ożdżyński 1997):

- Na samym wstępie pragnę usprawiedliwić się, dlaczego ulegając prośbie Szanownej Redakcji, w pierwszym artykule traktującym o telewizji wybrałem właśnie system... 
— Weźmy teraz do ręki jakiekolwiek ilustrowane czasopismo i przypatrzmy się na jakąkolwiek ilustrację.

— Posłuchajmy więc, na czym on polega... [T, 9/10 1938].

Co ciekawe, w wielu artykułach redagowanych prymarnie w funkcji deskryptywnej, zawierających realistyczne obrazowanie, pojawiały się - głównie w strukturach finalnych (np. w konkluzjach), w otoczeniu paratekstowym lub w sąsiedztwie infografiki (np. jako komentarz dołączony do ryciny, wykresu, fotografii) - fragmenty zdradzające myślenie magiczne, życzeniowe, baśniowe, antropomorficzne, ewokujące scenariusz marzenia o dobrodziejstwach płynących z nauki w „nowym, wspaniałym świecie” (por. Filar 2012). Te rozwiązania komunikacyjne ,doprowadzały do zlikwidowania abstrakcyjności przekazywanych treści” (za: Piekot 2002, s. 45) ${ }^{15}$. Spójrzmy na przykłady:

— Ten samochód, który zwijałby swoje skrzydla, jak ptak, mógłby krążyć po ziemi, jak zwyczajny automobil naszych czasów [T, 7/1937].

- Widoki, jakie przedstawiają się ludziom, którzy jako pierwsi opuszczą ziemię, będą oczywiście niezwykłe [...] nadzieje „astronautyków”, tych „przyszlych żeglarzy eteru” [KNL, 24 stycznia 1929].

- I proszę sobie uprzytomnić wspaniały obraz techniki! Setki pociągów pędzących dniem i nocą w różnych kierunkach, tysiące maszyn [KNL, 25 stycznia 1926].

— [o planetarium] Wyobraźmy sobie rodzaj cyrku, mieszczącego 1000 widzów [...]. Ale co za magiczna latarnia! [...] Przedstawienie się zaczyna $[\ldots]$. Widzowie [...] mogą podziwiać ten balet niebieski [...]. I znowu zajaśnia dzień. Schodzimy z ,wyżyn eteru”. Wielkość i upadek [...] [T, 5/1937]. — Samoloty wszystkie będą zaopatrzone [tak] [...], że każdy będzie mógł wsiąść na aeroplan na podworcu swojego domu i wylądować na dachu swego biura [KNL, 24 kwietnia 1929].

Być może w ten - nieco zbeletryzowany — sposób dziennikarz, prezentując atrakcyjną poznawczo tematykę (rozwój motoryzacji, fizyka fal radiowych, konstrukcje kolejowe czy architektura paryskiego planetarium), chciał oddać aurę intelektualną swoich czasów. Pozbawił więc narrację prasową naukowego rygoru, a narzucił jej właściwą epoce konwencję kulturowo-artystyczną (modernizm, sztuka futurystyczna i awangardowa powielająca hasło ' 3 razy M: miasto - masa - maszyna') lub pisarską (narodziny i dynamiczny rozwój prozy science fiction, np. Aldousa Huxleya). Trzeba pamiętać, że nauka dwudziestolecia dopiero po-

15 Więcej na temat figuratywności i wariantywności czy heterogeniczności stylu przekazu (popularno)naukowego także w: (Ożdżyński, Rittel (red.) 1997; Pelc 2000; Ossowski 2000, Piętkowa 2005) oraz (Lisowska-Magdziarz 2006; Hyland 1998). Na temat wykorzystania metafory pochodzącej z dyskursu naukowego w tekstach popularnonaukowych w monografii M. Zawisławskiej (2011, s. 112). Ten typ przenośni wykorzystywanej w mediach na potrzeby popularyzacji badaczka nazywa metaforą dydaktyczną/egzegetyczną. 
szukiwała teorii i praktycznych odkryć, które dla człowieka XXI wieku mieszczą się w sferze codziennych (zwyczajnych i potocznych) doświadczeń lub są fragmentem historiografii. Dlatego też komponenty semantyczne obrazujące czasoprzestrzeń (niebo i kosmos jako wyżyny eteru, magiczna latarnia, cyrk, widowisko), ruch (pędzić, opuszczać ziemię, żeglować, lecieć po niebie, w kosmosie) czy animizacje (samochód, automobil rozwijatby swoje skrzydta) dziś brzmią nieco poetycko. W dwudziestoleciu, w którym rodziła się teoria względności, a człowiek starał się przekroczyć granicę atmosfery, taki opis pobudzał do marzeń, do odkrywania nowych prawd naukowych.

\section{Ukryte treści ideologiczne w przedwojennym dyskursie popularyzatorskim}

W medialnym przekazie o nauce (a więc także we fragmencie całego dyskursu publicznego) na zbiorową (społeczną) świadomość silniej oddziałują wartości instrumentalne wiedzy (praktyczne pomysły i modele reform życia społecznego) niż jej wartości autoteliczne, kulturowe (modele poznawcze i paradygmaty teoretyczne) (por. m.in. Gajda 2013). Czytelnik, sięgający po artykuł popularnonaukowy, częściej chce się dowiedzieć, co wniesie praca badawcza do jego codzienności lub do życia społecznego, a nie jakie są dzieje myśli teoretycznej (por. Kowalewska 1989). Jak pisze Marek Kuś - pokazując wady i niebezpieczeństwa popularyzacji w jej wersji zmediatyzowanej (,zmedializowanej”) — „przeciętny odbiorca popularnych informacji naukowych przyzwyczajony jest do widzenia nauki wyłącznie jako źródła postępu technicznego" (Kuś 2004, s. 35).

W latach 1918-1939 nauka polska silnie uzależniła się od mecenatu państwa (por. Bogucka 2008; Wrona 2005; Brzoza, Sowa 2006), a nad techniką i pracami badawczymi patronat objęły ośrodki gospodarcze i przemysłowe (Orłowski 2012). Prasa więc oddawała panujący w latach dwudziestych i trzydziestych XX wieku „nastrój intelektualny” (określenie Ludwika Flecka — por. Gajda 2013), wzmacniała na użytek dyskursu publicznego autorytet instytucji naukowych, a jednocześnie legitymizowała osiągnięcia naukowe na użytek polityki państwa (zjawisko to T. Woźniak, 2000, nazywa „propagandą scjentystyczną”; por. Kuś 2004).

Pozytywne wartościowanie „cudów nauki i techniki” zderzało się też często z krytyką stanu gospodarki lub światowej konkurencji przemysłowej (głównie w okresach kryzysu na początku lat dwudziestych i w połowie lat trzydziestych). Badania w dyscyplinach ścisłych pod koniec lat trzydziestych — w obliczu niebezpieczeństwa wybuchu wojny, trwającego wyścigu zbrojeń (to zestawienie leksykalne często pojawia w nagłówkach IKC) - pokazywane były z perspektywy ideologicznej, a praca badawcza - jako składnik patriotyzmu (na temat ideologizacji nauki m.in. w: (Kamińska-Szmaj, Piekot, Poprawa (red.) 2009). Ten zmieniający 
się klimat sporów o kształt polskiej nauki i techniki, a zarazem kultury, Norman Davies nazwał ,atmosferą sukcesu zmieszaną z goryczą” (Davies 2008, s. 892).

Dziennikarze, pisząc o nauce jako bardzo ważnym komponencie życia w odradzającym się demokratycznym państwie, zarówno zamieszczali narracje o wiedzy naukowej z „perspektywy historii poszukiwań i dociekań naukowych”, jak i relacjonowali informacje o osiągnięciach badawczych „w aspekcie korzyści i zagrożeń" (określenia Goćkowskiego 2004, s. 61) dla polityki państwowej. Stąd też w wielu przekazach tamtego czasu — jak pisałem wcześniej — obecność strategii komunikacyjnych zdradzających ich ukształtowanie ideologiczne, a nawet nacechowanie propagandowe.

Przykładem tego zjawiska są choćby kampanie prasowe poświęcone polskiemu przemysłowi chemicznemu czy zbrojeniowemu. Wyrażano w nich liczne pochwały dla władzy i jej polityki, wykorzystując bardzo często kolokacje, w których pojawiały się „obowiązkowo" przymiotniki wyznaczające aspekt narodowy wartościowania (polski, rodzimy, krajowy, narodowy + geniusz, projekt, twórca, wynalazek, myśl itp.). Przykładowo spójrzmy na fragment relacji z wizyty władz w zakładach azotowych w Tarnowie-Mościcach, zamieszczonej w „Ilustrowanym Kurierze Codziennym" :

Niechaj więc wolno będzie na łamach „IKC” także ze strony technicznej zdać sprawę ze sposobu fabrykacji i ogromu wykonanej pracy, przynoszącej zaszczyt, co z naciskiem podkreślamy w pierwszym rzędzie, nie komu innemu, tylko technice polskiej. Wszak fabryka Mościcka jest dziełem par excelance techniki polskiej [IKC, 20 stycznia 1930].

Bohaterem wielu artykułów popularnonaukowych był Ignacy Mościcki, profesor chemii, prezydent, a zarazem współtwórca koncernu chemicznego w tarnowskich Mościcach. O jego twórczości naukowej pisano w sposób uwznioślający, a zarazem wychwalano zasługi w sanacyjnym obozie rządowym. Wartościowaniu leksykalnemu towarzyszyły zwykle nacechowane nominacje, wzmacniane zapisem wielką literą, np.:

„Majestat - Wynalazcą” $\rightarrow$ [nagłówek artykułu zawierający metonimię uwznioślającą prezydenta Mościckiego];

Jego genialny mózg oddat się z zapatem temu zagadnieniu $i$... rozwiazat je [...] nasz Wielki Wynalazca $[\mathrm{T}, 2 / 1938] \rightarrow$ [hiperbolizacja w korpusie tekstowym].

W wielu tekstach pojawiały się również strategie perswazyjne, za pomocą których dziennikarze piszący o nauce wywoływali dyskusję o zbiorowym obowiązu, kulcie miłości do ojczyzny, o działalności naukowej traktowanej jako praca/stużba społeczna. Leksyka normatywno-dydaktyczna, odwołująca do etosu obywatelskiego, umacniała więc w tekście - mniej lub bardziej — kontekst ideologiczno-propagandowy, por.: 
Coraz groźniejsze chmury pojawiają się na firmamencie, coraz to nowsze wyłaniają się konflikty [...]. Stąd też wyścig zbrojeń, stąd też kult dla armii [...] [T, 1/1938].

Kult miłości dla Ojczyzny nakazuje, że w poszczególnych państwach pracuje sztab naukowców [...], którzy dokonują różnych ciekawych odkryć z dziedziny obronności swego kraju [T, 1/1938].

\section{Budowa metra w Warszawie powinna być poparta przez całe społeczeń- stwo [T, 9/10 1938].}

Każdy praktyczny wynalazek należycie wykorzystany podnosi gospodarkę krajową [T, 5/1938].

Obrazom wychwalającym zasługi naukowców i polityków w dziedzinie modernizacji państwa towarzyszyła również debata na temat sytuacji (materialnej, prawnej czy społecznej) nauki w Polsce. Kontekst społeczny, polityczny, prawny dyskursu popularyzatorskiego determinował wybór przez nadawców strategii aksjologicznych, za pomocą których wprowadzano do tekstów — obok podstawowych ram tematycznych orzekających o świecie nauki - także inne tematy poboczne o zabarwieniu ideologicznym. Krytykowano np. rodzimy konserwatyzm światopoglądowy i tradycjonalizm, a wychwalano postęp naukowy w krajach uprzemysłowionych:

— za pomocą porównań implikujących kontrast 'postęp — zacofanie': To, co dla zagranicy jest starzyzna, u nas [...] pozostanie nie tylko marzeniem czy fantazja, ale wprost utopia [T, 5/1937];

— za pomocą zestawień dychotomicznych typu 'rozwój cywilizacyjny zacofanie': Dziś caty świat cywilizowany nie używa innego mleka, jak pasteuryzowanego [...], tylko Polska jest krajem, gdzie utrzymuje się poczciwa maksyma, $\dot{z}$ e ,ojcowie tak robili i żyli, więc i ja tak będę robit” [T, 5/1937];

— za pomoca presupozycji, aluzji, gier komunikacyjnych na temat braku uregulowanej polityki naukowej (np. dokonania polskiej techniki mają charakter muzealny, czyli 'dawny, nieprzydatny'): [Telewizja polska] Będzie mieć dwojaki szyld: jeden w języku polskim ,Stacja telewizyjna”, i dla obcokrajowców w odpowiednich wersjach: ,Muzeum telewizyjne” [T, 9/10 1938] ${ }^{16}$.

16 Przykład ten wymaga dodatkowego komentarza. Telewizja nie jest medium, które można by w historii techniki i cywilizacji powiązać bezpośrednio z dorobkiem dwudziestolecia międzywojennego. Pierwszy polski odbiornik telewizyjny zaprojektowano w 1929 roku i przedstawiono na targach poznańskich, od 1935 trwały przygotowania do produkcji masowej. Trzeba jednak dopowiedzieć, że pierwsze plany konstrukcyjne pojawiły się w Polsce w 1938. Planowano nawet utworzenie stacji telewizyjnej (tzw. Doświadczalnej Stacji Telewizyjnej) w gmachu warszawskiego „drapacza chmur" (czyli w budynku towarzystwa ubezpieczeniowego Prudential), jednak wojna przerwała te prace badawcze. Techniczne aspekty telewizji były opisywane przez prasę w licznych dodatkach poświęconych nauce już z początkiem lat trzydziestych. Więcej na ten temat w syntezach historycznych. 
Również nierzadko deprecjonowano takie zjawiska, jak: brak nakładów finansowych na badania naukowe, niskie wynagrodzenie, ubóstwo badaczy ( $n e ̨ d z a$, zapomnienie) oraz brak regulacji $\mathrm{w}$ zakresie prawa patentowego (machinacje, oszustwa, fatszerstwa), por.:

Fikcje, oszustwa, fałszerstwa. Oto metody N.V. Philipsa, który [...], niszczy niezależność polskiego przemysłu radiowego, ukrócenie tych machinacyj [T, 7/1937];

Ile czasu upłynie jeszcze do tej chwili, w której wynalazcy polscy przestaną żyć w nędzy i zapomnieniu, a otoczeni będą szacunkiem i dobrobytem? [T, 9/10 1938].

\section{Wnioski}

Sprawy nauki zajmowały wiele miejsca w prasie dwudziestolecia międzywojennego. O wynalazkach, odkryciach, teoriach naukowych pisano, ujawniając wiele emocji i na ogół zachwytu. Był to więc przekaz społecznie zaangażowany — zarówno pod względem edukacyjnym, jak i ideologiczno-propagandowym.

Same zaś strategie popularyzacji na pewno w mniejszym stopniu niż dziś czerpały z elementów krzykliwej perswazji. W tekstach pojawiały się skromne rozwiązania ikonograficzne, stąd też w przedstawionym opracowaniu pominięto ich analizę. Trzeba dodać, że jeśli już się pojawiały, zawierały zwykle bardzo realistyczne środki wizualizacji, a gra między płaszczyzną werbalną a wizualną ujawniała się wyłącznie w rysunkach przedstawiających ryciny projektów inżynieryjnych (np. samolotów, samochodów, elektrowni itp.). Elementem wyrazistym dyskursu popularnonaukowego badanego okresu są zaś niezwykle emotywnie nacechowane prasowe sylwetki badaczy. Za zjawisko wyróżniające pisarstwo popularnonaukowe lat 1918-1939 należałoby uznać również obecność licznych konwencji narracyjnych, które pokazują bieżące pomysły naukowe w perspektywie rozważań z pogranicza beletrystyki, futurologii lub myślenia magicznego.

\section{Bibliografia}

Bartmiński J. (2006), Językowe podstawy obrazu świata, Lublin.

Biniewicz J. (2011), Interakcje komunikacyjne $w$ dyskursie naukowym (na przykładzie pierwszych polskich tekstów naukowo-dydaktycznych, technicznych), [w:] Poznawać. Tworzyć. Komunikować. Dyskursy komunikacji medialnej, red. A. Filipczak-Białkowska, Łódź.

Bogucka M. (2008), Kultura, naród, trwanie. Dzieje kultury polskiej od zarania do 1989 roku, Warszawa.

Brzoza C., Sowa A.L. (2006), Historia Polski 1918-1945, Kraków.

Davies N. (2008), Boże igrzysko. Historia Polski, Kraków. 
Filar D. (2012), Narracyjne aspekty językowego obrazu świata. Interpretacja marzenia we wspótczesnej polszczyźnie, Lublin.

Gajda S. (1990), Wspótczesna polszczyzna naukowa. Język czy żargon?, Opole.

Gajda S. (1999), Wspótczesny polski dyskurs naukowy, [w:] Dyskurs naukowy - tradycja i zmiana, red. S. Gajda, Opole.

Gajda S. (2010), Prestiż a język, „Nauka”, z. 4.

Gajda S. (2013), Styl naukowy, [w:] Style wspótczesnej polszczyzny. Przewodnik po stylistyce polskiej, red. E. Malinowska, J. Nocoń, U. Żydek-Bednarczuk, Kraków.

Goćkowski J. (1984), Autorytety świata uczonych, Warszawa.

Goćkowski J. (2004), Uczony i dziennikarz w grze o charakter obecności nauk w społeczeństwie, [w:] Medializacja nauki, red. B. Gruszka, Warszawa.

Gruszka B. (red.) (2004), Medializacja nauki. Fundacja dyskusji o nauce, z. 8, Warszawa.

Hyland K. (1998), Persuasion and context: The pragmatics of academic metadiscourse, „Journal of Pragmatics" 30.

Kaczmarek R. (2010), Historia Polski 1914-1989, Warszawa.

Kamińska-Szmaj I., Piekot T., Poprawa M. (red.) (2009), Oblicza Komunikacji. Ideologie codzienności, Wrocław.

Kowalewska S. (red.) (1989), Wartości nauki w społecznej świadomości, Wrocław.

Kuś M. (2004), Niebezpieczeństwa medializacji i popularyzacji nauki, [w:] Medializacja nauki, red. B. Gruszka, Warszawa.

Lisowska-Magdziarz M. (2006), Medialne reprezentacje wiedzy, [w:] Komunikowanie (sie) w mediach elektronicznych. Język, edukacja, semiotyka, red. M. Filiciak, G. Ptaszek, Warszawa.

Lisowska-Magdziarz M. (2011), Media powszednie. Środki komunikowania masowego i szerokie paradygmaty medialne w życiu codziennym Polaków u progu XXI wieku, Kraków.

Martin R.J., Veel R. (red.) (2005), Reading Science. Critical and Functional Perspectives on Discourses of Science, London-New York.

Mencwel A. (2004), Magia i nauka, [w:] Medializacja nauki, red. B. Gruszka, Warszawa.

Miodek J., Zaśko-Zielińska M. (red.) (2002), O trudnym łatwo. Materiały sesji poświęconej popularyzacji nauki, Wrocław.

Orłowski B. (2012), Polski wkład do techniki światowej i dorobku technicznego innych krajów, [w:] Polskie dziedzictwo kultury i nauki, red. E. Szczepanik, Torun.

Ossowski S. (1967), Dzieła, t. IV. O nauce, Warszawa.

Ossowski S. (2000), Język nauk społecznych na tle zagadnień teorii kultury (fragment), [w:] Język wspótczesnej humanistyki, red. J. Pelc, Warszawa (fragment za: S. Ossowski, Dzieła, t. IV. O nauce, Warszawa 1967).

Ożdżyński J. (1997), Niektóre cechy dyskursu edukacyjnego (na przykładzie wypowiedzi wyktadowej), [w:] Dyskurs edukacyjny, red. J. Ożdżyński, T. Rittel, Kraków.

Ożdżyński J., Rittel T. (red.) (1997), Dyskurs edukacyjny, Kraków.

Paczkowski A. (1980), Prasa polska w latach 1918-1939, Warszawa.

Paczkowski A. (2004), Nauka w mediach. Nieco luźnych uwag, [w:] Medializacja nauki, red. B. Gruszka, Warszawa.

Pałucka-Czerniak I. (2008), Zmagania z dystansem. O języku przedmów do polskich publikacji naukowych, Zielona Góra.

Pałuszyńska E. (2006), Nagłówki w „, Gazecie Wyborczej” (ekspresywna leksyka, frazematyka, metaforyka), Łódź.

Pawłowski A. (2011), Nauka o mediach i komunikacji. Próba oceny stanu dyscypliny, [w:] Komunikowanie (sie) w mediach elektronicznych. Język, edukacja, semiotyka, red. M. Filiciak, G. Ptaszek, Warszawa.

Pelc J. (2000), Język współczesnej humanistyki, Warszawa.

Pelc J. (2000), Myśli o języku humanistyki, [w:] Język wspótczesnej humanistyki, red. J. Pelc, Warszawa. 
Piekot T. (2002), Mechanizmy popularyzowania wiedzy naukowej, [w:] O trudnym łatwo. Materiaty sesji poświęconej popularyzacji nauki, red. J. Miodek, M. Zaśko-Zielińska, Wrocław.

Piekot T. (2006), Dyskurs polskich wiadomości prasowych, Kraków.

Piętkowa R. (2005), Dyskurs naukowy a retoryka, [w:] Wspótczesne analizy dyskursu, red. M. Krauz, S. Gajda, Rzeszów.

Stanulewicz D. (2002), Tytuły artykułów prasowych traktujących o języku, [w:] O trudnym tatwo. Materiały sesji poświęconej popularyzacji nauki, red. J. Miodek, M. Zaśko-Zielińska, Wrocław.

Starzec A. (1997), Edukacyjne walory tekstów popularnonaukowych, [w:] J. Ożdżyński, T. Rittel (red.), Dyskurs edukacyjny, Kraków.

Starzec A. (1999), Współczesna polszczyzna popularnonaukowa, Opole.

Starzec A. (2002), Przemiany w popularyzacji prasowej, [w:] O trudnym łatwo. Materiały sesji poświęconej popularyzacji nauki, red. J. Miodek, M. Zaśko-Zielińska, Wrocław.

Starzec A. (2013), Styl popularnonaukowy — styl dyskursu popularnonaukowego, [w:] Style wspótczesnej polszczyzny. Przewodnik po stylistyce polskiej, red. E. Malinowska, J. Nocoń, U. Żydek-Bednarczuk, Kraków.

Uniwersalny stownik języka polskiego PWN, red. S. Dubisz, Warszawa 2003 (wersja elektroniczna),

Woźniak T. (2000), Propaganda scjentystyczna. Funkcje społeczne przekazów popularnonaukowych, Warszawa.

Wrona G. (1999), Naukowe czasopisma techniczne w Polsce w latach 1918-1939, „Rocznik Historii Prasy Polskiej" II, z. 2 (4).

Wrona G. (2005), Polskie czasopisma naukowe w latach 1918-1939, Kraków.

Wrona G. (2007), Polskie czasopisma popularnonaukowe w XIX wieku. Ewolucja formy i treści, „Rocznik Historii Prasy Polskiej” X, z. 2 (20).

Zawisławska M. (2011), Metafora w języku nauki. Na przykładzie nauk przyrodniczych, Warszawa. Zdunkiewicz-Jedynak (2008), Wyktady ze stylistyki polskiej, Warszawa.

Ziółkowski M. (2004), O dwóch postaciach medializacji nauki, [w:] Medializacja nauki, red. B. Gruszka, Warszawa.

\section{World of scientific discoveries in Polish popular press 1918-1939. The main strategies of popularization of knowledge in media discourse}

\section{Summary}

The author of the article has two research objectives. The first one is to describe and analyse main strategies of popularization of science in Polish press 1918-1939. The article also highlights some aspects, tendencies and reception of media text (media discourse): picture of the world of science and achievements, strategies used by journalists to write about difficult topics (e.g. translating difficult problems into easier stylistic form), used by them rules of "Plain Language". The second purpose of the article is to overview historical, cultural context and hidden implications (persuasive strategies) in the public discourse about the role of science in Poland before the Second World War.

Keywords: strategies of edutainment in Polish press 1918-1939, media discourse in Poland 1918-1939, strategies of popularization of knowledge in media discourse 